\title{
EVALUATION OF SOCIODEMOGRAPHIC, CLINIC AND THERAPEUTIC PROFILE IN PEOPLE WITH RHEUMATOID ARTHRITIS FROM A REFERENCE CENTER IN THE CITY OF SALVADOR
}

\author{
Cristiano Sena da Conceição \\ MSc, Adjunct Professor: Estacio-FIB, UFBA, Unime. \\ Doctoral student in Medicine and Human Health of \\ Bahiana School of Medicine and Public Health, Salva- \\ dor, Bahia, Brazil. \\ João Paulo Vieiro \\ Researcher at the group of technological innovation \\ in rehabilitation (UFBA), Salvador, Bahia, Brazil. \\ Selena M. D. Mendes \\ MSc, Assisten Professor, Bahiana School of Medicine \\ and Public Health, Salvador, Bahia, Brazil. \\ Uibirá C. Barbosa Undergraduate Physical Therapy student, Estácio-FIB. \\ Kátia Nunes Sá PhD, Adjunct Professor, Bahiana School of Medicine \\ and Public Health, Salvador, Bahia, Brazil.
}

Corresponding author

Cristiano Sena da Conceição

E-mail: cristianosena@gmail.com

\begin{abstract}
Background: Rheumatoid arthritis (RA) is a chronic and autoimmune disease with unknown origin, characterized by inflammatory involvement of multiple joints. This study aimed to evaluate the sociodemographic, clinical and therapeutic profile for subjects with rheumatoid arthritis from a reference center in the city of Salvador. It was made a descriptive study with 97 individuals with RA. This sample was compose by $93 \%$ of female with age between 35 to 59 years (63\%), skin color Brown (47\%) and black (38\%) in C2 social class (40\%) and 35\% with school graduate schooling, 91(\%) presents pain: severe pain in $79(\%)$ nociceptive $(41 \%)$, mixed $(39 \%)$ and $14.4 \%$ was in use of medicines and physical therapy. These results allows reorganize the therapeutic and preventive approach to a specific profile. The therapeutics practicing are not enough to control a tissue wear, and the pain that became a limiter factor to the patient care success with RA.
\end{abstract}

Keywords: Rheumatoid arthritis; Sociodemographic profile; Clinical profile; Therapeutic profile. 


\section{INTRODUCTION}

Epidemiological studies have estimated the prevalence of Rheumatoid arthritis (RA) in $1 \%$ of the adult population, ranging from 0.4 to $1.9 \%$ in worldwide and 0.2 to $1.0 \%$ in Brazil. ${ }^{(1)}$ It is more frequent in women in a 3:1 ratio with the highest incidence among the 35-65 years. ${ }^{(2)}$ The systemic nature of RA and the pain affect both structures related to movement and other organ systems. Thus the global impairment impacts the ability to perform daily and also the quality of life by promoting reduction of life expectancy of three to seven years on average. ${ }^{(3)}$

\section{MATERIALS AND METHODS}

This is a descriptive study on sociodemographic characteristics, type of treatment and the presence of pain in individuals with rheumatoid arthritis from the collagen center of the Bahiana School of Medicine and Public Health. We included 97 individuals with a confirmed diagnosis of RA based on the criteria of the American College of Rheumathology. All participants signed an informed consent and the project was approved by the ethics committee and research of Bahiana School of Medicine and Public Health. (protocol 002/11).

The sociodemographic variables were: gender, age, social class, education, and race, clinical features (presence, intensity, type of pain and disease activity score) and therapeutics (type of treatment). The variable pain was assessed by visual analogue scale (VAS), an internationally validated and tested scale ${ }^{(4)}$ and disease activity score based on 28 pain joints with DAS28 calculator.

Descriptive variables were presented as mean and standard deviation for numeric variables and proportions for categorical variables. Cross tables were performed in SPSS software version. 14 to visualize association between variables.

\section{RESULTS}

The results were gathered in sociodemographics (gender, age, social class, schooling, race), clinical features (presence, intensity, type of pain and disease activity score) and therapeutics (type of treatment). The sample was compose by $93 \%$ of female with age between 35 to 59 years (63\%), skin color Brown (47\%) and black (38\%) in C2 social class (40\%) and 35\% with school graduate schooling. Pain was reported by $91(\%)$ of the sample, with severe pain level in 79(\%) distributed in: nociceptive (41\%), mixed (39\%) and neurophatic (18.6\%). 85. All the sample was with RA active. Related to therapy, $6 \%$ did not do physical therapy, $97 \%$ was in use of medicines 
and only $14.4 \%$ used medicines and physical therapy. Table 1 shows the association between level of pain and some variables sociodemographics (gender, age) clinicals (type of pain and disease activity score) and therapeutics (type of therapeutics).

Table 1 - Association between level of pain and some sociodemographics, clinical and therapeutics variables.

\begin{tabular}{|c|c|c|}
\hline \multirow[b]{2}{*}{ Variables } & \multicolumn{2}{|c|}{ Level of Pain } \\
\hline & Mild and Moderate & Severe \\
\hline \multicolumn{3}{|l|}{ Gender } \\
\hline Female & $17(18,9 \%)$ & $73(81,1 \%)$ \\
\hline Male & $03(42,9 \%)$ & $04(57,1 \%)$ \\
\hline \multicolumn{3}{|l|}{ Age (years) } \\
\hline $20-34$ & $03(30,0 \%)$ & $07(70,0 \%)$ \\
\hline 35 a 59 & $12(20,0 \%)$ & $48(80,0 \%)$ \\
\hline$\geq 60$ & $05(19,2 \%)$ & $21(80,8 \%)$ \\
\hline \multicolumn{3}{|l|}{ Type of pain } \\
\hline Neurophatic & $01(05,6 \%)$ & $17(94,4 \%)$ \\
\hline Nociceptive & $11(27,5 \%)$ & $29(72,5 \%)$ \\
\hline Mixed & $07(18,9 \%)$ & $30(81,1 \%)$ \\
\hline \multicolumn{3}{|c|}{ Disease Activity Score } \\
\hline Mild & $01(100 \%)$ & $00(0 \%)$ \\
\hline Moderate & $12(38,7 \%)$ & $19(61,3 \%)$ \\
\hline High & $07(10,9 \%)$ & $57(89,1 \%)$ \\
\hline \multicolumn{3}{|c|}{ Use of medicines } \\
\hline No & $01(50,0 \%)$ & $01(50,0 \%)$ \\
\hline Yes & $19(20,2 \%)$ & $75(79,8 \%)$ \\
\hline \multicolumn{3}{|c|}{ Use of physical therapy } \\
\hline No & $19(23,2 \%)$ & $63(76,8 \%)$ \\
\hline Yes & $01(7,1 \%)$ & $13(92,9 \%)$ \\
\hline
\end{tabular}

\section{DISCUSSION}

The results demonstrate that most of the sample is female gender. It can be explained by two reasons: most attendance of RA in female gender ${ }^{(3: 1)(2)}$ and most of women looking for health care services. ${ }^{(5,6,7)}$

By IBGE information $^{(8)}$ in $2009,82,7 \%$ of Salvador population are compounded by black and brown people, as well as low family income and low schooling. It infor- 
mation make clear the reason why this study found most people with brown and black skin color in C1 and C2 social class. Many studies ${ }^{(2,5,7)}$ demonstrates that RA presents high incidence around 35 to 65 years old. It was confirmed by this research results. On this age range, inflammatory process recurrent commits movement structures functions that causes pain and interferes within daily works quality. Pain is the principal reason that takes this people to looking for health care professional. ${ }^{(3,5)}$

On this work, pain was presented in $91 \%$ of the sample, whit severe pain in $79 \%$. When assesses the pain intensity with gender (table 1), become clearly that there are an unequal distribution between sexes. Severe pain was presented in $81 \%$ of female gender. It is important to point that on male, the pain was distributed in homogeneous manner between severe and mild/moderate pain. This result could have been influenced by a sample consisting mostly of female gender, however it suggests that compare to men, women have severe pain more than men.

Severe and disabling pain is a common event on people with RA, presenting incidence on studies with this specific population. ${ }^{(1,2)}$ Once that RA commits essentials joints for daily works, the severe pain configures as the most restriction factor that deserves attention by the health care professional. ${ }^{(5,6,7)}$

The most presence of nociceptive and mixed pain is indicative that pain in the individuals with RA is in the most of cases explained by wear tissue process that comes from inflammations. This dysfunction causes accumulation of inflammatory markers that intensify the neural input of chemoreceptor, while the deformity increases the mechanoreceptors and the stimulus of pathway. ${ }^{(9)}$

Analyzing the association between age, type and intensity of pain, it is possible to infer that that severe pain is more common in different age ranges, all types of pain and therapeutics with homogeneous distribution, see table 1.

The variable analysis "type of treatment", permits identifying that the most part of the sample (97\%) uses medicines and don't physical therapy (85\%). It reveals that in this specific populations, treatment of rehabilitation, like physical therapy (10), even with patient with large dysfunction of musculoskeletal system is not widely used, it because is not easily accessible in function of the costs and the distances from health services centers or because the RA is a systemic disease without definite cure, what it can be viewed as a barrier to retention in prolonged treatments such as physical therapy.

The different levels of disease activity score, showed in table 1, reveals that RA is active, and thus, the results of this study can be considered within the standards of current publications involving this specific population. 


\section{CONCLUSION}

Even taking medicines, the pain is a constant fact on this sample. The most severe pain is frequent, nociceptive and mixed present on female gender more than the man, and doesn't matter the age range. These results allow that the organizations and health care professionals reorganize the therapeutic and preventive approach. Special attention might be taken to the disseminations knowledge be made in adequate form to this populations profiling, as well as the pain results reveals that therapeutics cares practicing are not enough to control a tissue wear, dysfunction and pain. In fact, it can be considered as a limiter factor to the patient treatment success therefore, news studies might be make to become possible news applications of therapeutics and preventive approach with RA individuals.

\section{REFERENCES}

1. Tarigoe DY, Laurindo IMM. Artrite reumatóide e doenças cardiovasculares. Rev. bras. Reumatol; 2006.

2. Abreu MM, Kowalsi SC, Ciconelli RM, Ferraz MB. Avaliação do perfil sociodemográfico, clínicolaboratorial e terapêutico dos pacientes com artrite reumatóide que participaram de projetos de pesquisa na Escola Paulista de Medicina, nos últimos 25 anos. Revista Brasileira Rev. bras. Reumatol. 2006;46(2).

3. Cotran RS, Kumar V; Collins T. Patologia estrutural e funcional. 6. ed. Rio de Janeiro: Guanabara Koogan; 2000. 1365 p.

4. Campbell WL, Lewis S. Visual Analogue Measurement of pain. Ulster Med J. 1990;59:149-59

5. Mota LMH, Cruz BA, Brenol CV, Pereira, IA, Rezende_Fronza LS, Bertolo, MB, Freitas MVC, Silva NA, Louzada_Junior, P, Giorgi RDN, Lima RAC, Pinheiro GRC. Consenso 2012 da Sociedade Brasileira de Reumatologia para o tratamento da artrite reumatoide. Rev. bras. Reumatol; 2012; 52(2)135-174.

6. Corbacho MI, Dapueto JJ. Avaliação da capacidade funcional e da qualidade de vida de portadores com artrite reumatoide. Rev. bras. Reumatol. 2010;50(1).

7. Mota LMH, Laurindo IMM, Neto LLS. Avaliação prospectiva da qualidade de vida em uma coorte de portadores com artrite reumatoide inicial. Rev. bras. Reumatol. 2010;50(3):249-61.

8. IBGE. Rendimento Mensal de Negros e Pardos na região metropolitana de Salvador. [acesso em: 24 Maio 2013]. Disponível em: http://saladeimprensa.ibge.gov.br/pt/noticias? view=noticia\&id=1\&id noticia $=1370 \&$ busca $=\& \mathrm{t}=$ rendimento-trabalhadores-pretos-pardos-equivale-metade-que-recebembrancos>

9. SÁ, KN, Baptista AF, Matos MA, Lessa I. Prevalência de dor crônica e fatores associados na população de Salvador, Bahia. Rev. Saúde Pública. 2009;43(4):622-630.

10. Kavuncu V, Evcik D. Physiotherapy in Rheumatoid Arthritis. MedGenMed. 200;6(2).

11. Alishri GH, Bayat N, Salimzadeh A, Salari A, Hosseini SM, Rahimzadeh S, Assari S. Healthrelated quality of life and disease activity in rheumatoid arthritis. J Res Med Sci. 2011;16(7):897-903. 